\title{
SUSTAIN program: klinikai eredmények
}

\author{
Balogh Zoltán dr.
}

\section{Összefoglalás}

A 2-es típusú diabetes mellitus korábbi, döntöen a glykaemiás kontrollra fókuszáló terápiás megközelítése helyett a legújabb nemzetközi ajánlások multifaktoriális kezelést preferálnak. A heti egyszeri, subcutan alkalmazandó GLP-1-receptoragonista szemaglutid új kezelési lehetöség az életmódterápia kiegészitésére a 2-es típusú cukorbetegek glykaemiás állapotának javitására. Napjainkban a GLP-1-receptoragonisták az elsöként választandó injektábilis vércukorcsökkentő készitmények. A SUSTAIN 1-5 3a fázisú és a SUSTAIN-7 3 b fázisú klinikai program a heti egyszeri GLP-1-receptoragonista szemaglutid hatékonyságát és biztonságosságát vizsgálta 2-es típusú cukorbetegeken placebóval, valamint különbözö aktiv komparátor vércukorcsökkentö gyógyszerekkel összehasonlítva (nevezetesen szitagliptinnel, heti egyszeri exenatiddal, dulaglutiddal és glargin inzulinnal). A szemaglutid konzekvensen szuperioritást igazolt mind a tartós glykaemiás kontroll, mind a testsúlycsökkentö hatás tekintetében valamennyi vizsgált komparátor gyógyszerrel szemben. A jelen közleményben a SUSTAIN 1-5 és a SUSTAIN-7 klinikai program eredményeit, a hatékonysági és biztonságossági adatokat tekintjük át. Egyúttal a szemaglutid potenciális helyét is igyekszünk meghatározni a 2-es típusú diabetes mellitus kezelésének mindennapi gyakorlatában.

\section{Kulcsszavak: glukagon-like peptid-1 receptor agonista, szemaglutid, glykaemiás kontroll, testsúly, mellékhatások}

\section{SUSTAIN trial program: clinical results}

Summary: Current international therapeutic guidelines highlight the importance of multifactorial approach to management in type 2 diabetes, in contrast to previously focus mainly on glycemic control. Semaglutide once-weekly glucagon-like peptide-1 receptor agonist subcutaneous injection has been approved as an adjunct to lifestyle management to improve glycemic control in type 2 diabetes. Nowadays GLP-1-receptoragonists are generally recommended as the first injectable medication. SUSTAIN (Semaglutide Unabated Sustainability in Treatment of Type 2 Diabetes) is a phase $3 a$ and phase $3 b$ clinical trial program to investigate the efficacy and safety of once-weekly subcutaneous semaglutide with placebo as well as active comparator antihyperglycemic drugs (namely sitagliptin, exenatide extended-release, dulaglutide and insulin glargine) in patients across the spectrum of type 2 diabetes. Semaglutide consistently demonstrated superior and sustained glycemic control and weight loss vs. all comparators evaluated. This article overviews data from the SUSTAIN 1 to 5 and 7 clinical trial program, including efficacy and safety results and findings from post hoc analyses. Furthermore the potential place of semaglutide in everyday practice for management of type 2 diabetes is also discussed.

Keywords: glucagon-like peptide-1 receptor agonist, semaglutide, glycemic control, weight, side effects

Rövidítések

ADA: Amerikai Diabetes Társaság (American Diabetes Association); ApoB48: apolipoprotein-B48; Cl: konfidenciaintervallum; DPP-4: dipeptidilpeptidáz-4; EASD: Európai Diabetes Társaság (European Association for the Study of Diabetes); FFA: szabad zsírsav (free fatty acid); GLP-1: glukagonszerü peptid-1 (glucagon-like peptide-1); HbA $_{1 \mathbf{c}}:$ glikált hemoglobin; NYHA: New York Heart Association; RCT: randomizált, kontrollált tanulmány; SGLT-2: nátrium-glukóz kotranszporter-2 (sodium-glucose co-transporter-2); SUSTAIN: Semaglutide Unabated Sustainability in Treatment of Type 2 Diabetes; TIA: tranziens ischaemiás attak; T2DM: 2-es típusú diabetes mellitus; VLDL: nagyon alacsony sürüségü lipoprotein (very low-density lipoprotein) 
1 21. század elején világszerte szinte exponenciális mértékben növekszik a 2-es típusú diabetes mellitus gyakorisága. A diabetes akut és krónikus szövődményei nagymértékben rontják a betegek életkilátásait, életminőségét, valamint óriási gazdasági terhet rónak az egyes országok egészségügyi ellátó rendszereire.

A GLP-1-receptoragonisták a plazma glukózszintjétől függően serkentik a $\beta$-sejtek inzulinszekrécióját és hasonló módon gátolják az $\alpha$-sejtek glukagontermelését, minimális hypoglykaemia-rizikó mellett csökkentik a máj glukóztermelését, lassítják a gyomorürülést korai teltségérzést okozva, az agyban csökkentik az étvágyat, valamint megőrzik a $\beta$-sejtek működését, tartós glykaemiás kontrollt biztosítva, mindezt testsúlycsökkenés mellett.

A szemaglutidot az Amerikai Egyesült Államokban 2017 decemberében, Európában 2018 elején törzskönyvezték. A szemaglutid egy acilált, közel 1 hetes (165-184 óra közötti) felezési idejü, a humán GLP-1-gyel 94\%-os szerkezeti homológiát mutató, a szérumalbuminhoz a liraglutidnál 5,6-szorosan jobban kötődő GLP-1-receptoragonista, amely ellenáll a DPP-4 enzim lebontó hatásának. Kis molekulamérete (kb. $4 \mathrm{kDa})$ miatt a vér-agy gáton keresztül az éhséget és jóllakottságot vezérlő hypothalamusba, valamint a hedonikus (,jutalmazó, az étkezés kiváltotta örömérzést szabályozó, a kalóriadús, zsíros ételeket preferáló”) étvágyközpontokba, a limbikus rendszerbe egyaránt jól penetráló, heti egyszeri subcutan injekció formájában alkalmazandó hosszú hatású GLP-1-receptoragonista, amely receptorához nagy affinitással kötődik. ${ }^{1}$ A heti egyszer alkalmazott $0,5 \mathrm{mg}$ vagy $1,0 \mathrm{mg}$ szemaglutid kedvező kardiovaszkuláris hatásai a SUSTAIN-6 vizsgálatban igazolódtak. ${ }^{2}$ Az ADAEASD legutóbbi, 2018. októberi terápiás konszenzusnyilatkozatában a GLP-1-receptoragonisták az atherosclerotikus kardiovaszkuláris betegséggel társuló 2-es típusú diabetesben az életmódterápia és a metformin kiegészítésére a preferálandó antihyperglykaemiás szerek közé kerültek, hasonlóan a kardiovaszkuláris előnyt igazoltan felmutató SGLT-2-gátlókhoz, ${ }^{3}$ egyúttal kiemelten fontos a minimális hypoglykaemia-rizikó melletti testsúlycsökkentő hatásuk.

A szemaglutiddal a 2-es típusú diabetes igen széles klinikai spektrumát érintő több $3 a$, valamint 3 b fázisú vizsgálatot végeztek el. ${ }^{4}$ Ezen klinikai tanulmányok közül a 3a fázisú SUSTAIN $1-5$, valamint a 3 b fázisú SUSTAIN-7 vizsgálatok fontosabb hatékonysági és biztonságossági adatait tekintjük át a közleményben. Az összesen 5098 randomizált, 2-es típusú cukorbeteg beválasztási és kizárási kritériumai hasonlóak voltak a fenti vizsgálatokban. 18 év fölötti, 2-es típusú diabetes, kiindulási $\mathrm{HbA}_{1 \mathrm{c}}$-érték 7,0-10,0\% (53-86 $\mathrm{mmol} / \mathrm{mol}$ ) közötti volt a SUSTAIN-1, -4, -5-ben, illetve 7,0-10,5\% (53-91 mmol/mol) közötti volt a SUSTAIN-2, -3, -7-ben. Kizáró tényező volt az egyéni anamnézisben szereplő krónikus vagy idiopathiás akut pancreatitis, az egyéni vagy családi előzményben szereplő medulláris pajzsmirigyrák, illetve 2-es típusú multiplex endokrin neoplasia, vagy $>50 \mathrm{ng} / \mathrm{l}$ szérumkalcitonin-szint, a randomizáció előtt 3 hónapon belüli akut coronaria- vagy cerebrovascularis esemény, a NYHA IV. stádiumú szívelégtelenség, valamint a vizsgáló orvos szerint akut kezelést igénylő ismert proliferatív retinopathia vagy maculopathia. A SUSTAIN-7-ben további kizáró tényező volt a szűrés előtti 180 napon belüli szívinfarktus, stroke, instabil angina pectoris és/vagy TIA miatti hospitalizáció. ${ }^{1}$

\section{SUSTAIN-1}

A 30 hetes kettős vak, placebokontrollos, multicentrikus vizsgálatban 387, diétával és testmozgással nem megfelelően kontrollált 2-es típusú cukorbeteget randomizáltak heti egyszer $0,5 \mathrm{mg}$, heti egyszer 1,0 mg szemaglutid vagy előtöltött PDS290 pen-injektorral beadott placebokezelésre. A 0,5 mg szemaglutidot kapó betegek $\mathrm{HbA}_{1 \mathrm{c}}$-értéke 1,45\%-kal (95\%-os CI: 1,26-1,65), az 1,0 mg-ot kapók csoportjában 1,55\%-kal (95\%-os CI: 1,36-1,74) csökkent (mindkettő szignifikáns, $\mathrm{p}<0,0001$ a placebóval szemben), ahol nem szignifikáns mértékben, $0,02 \%$-kal csökkent a $\mathrm{HbA}_{1 \mathrm{c}}$ értéke $(95 \%$-os CI: $0,18-0,23)$. A testsúly a $0,5 \mathrm{mg}$ szemaglutid mellett szignifikánsan ( $\mathrm{p}<0,0001), 3,73 \mathrm{~kg}$-mal (95\%-os CI: 2,91-4,54), az 1,0 mg-os csoportban átlagosan 4,53 kg-mal (95\%-os CI: 3,72-5,34) csökkent ( $\mathrm{p}<0,0001$ ), a placebocsoportban $0,98 \mathrm{~kg}$-mal mérséklődött (95\%-os CI: 0,13-1,82). Leggyakoribb mellékhatás az émelygés volt (sorrendben: 20, 24, illetve $8 \%$-ban), míg hasmenés sorrendben: 13,11 , illetve a placebocsoportban $2 \%$-ban volt észlelhetö. ${ }^{5}$ 


\section{SUSTAIN-2}

A SUSTAIN-2 56 hetes, a változatlan dózisú metformin, thiazolidindion vagy e kettő kombinációja ellenére nem megfelelően kontrollált $\left(\mathrm{HbA}_{1 \mathrm{c}}\right.$ 7,0-10,5\% között) 2-es típusú diabeteses egyének heti egyszer $0,5 \mathrm{mg}$, vagy heti $1,0 \mathrm{mg}$ szemaglutidot, illetve aktív komparátorként napi 100 mg szitagliptint kaptak. Elsődleges végpont az 56 hetes vizsgálat végére elért $\mathrm{HbA}_{1 \mathrm{c}}$-csökkenés, másodlagos végpont a testsúly változása és a hypoglykaemiás és adverz események gyakorisága volt. 1225 beteget randomizáltak a három gyógyszeres karra. A heti $0,5 \mathrm{mg}$ szemaglutidot kapó 409 betegben átlagosan 1,3\%-kal, a 409, heti 1,0 mg szemaglutidot alkalmazók között átlagosan 1,6\%-kal, szignifikánsan csökkent a $\mathrm{HbA}_{1 \mathrm{c}}$ értéke, míg a napi 100 mg szitagliptint kapók csoportjában (407fö) a $\mathrm{HbA}_{1 \mathrm{c}}$-érték mindössze $0,5 \%$-kal mérséklődött. A testsúly a kiindulási, átlagosan 89,5 kg-ról sorrendben 4,3, az 1,0 mg szemaglutid esetén 6,1, míg napi $100 \mathrm{mg}$ szitagliptin mellett $1,9 \mathrm{~kg}$-mal csökkent. Mind a glykaemiás, mind a testsúlyra gyakorolt hatás tekintetében a szemaglutid egyaránt szuperioritást mutatott a szitagliptinnel szemben $(\mathrm{p}<0,0001)$. Az adverz (főleg emésztőszervi) események miatt a gyógyszerszedés abbahagyása sorrendben 8,10 , illetve szitagliptin esetén $3 \%$ volt. Émelygés sorrendben 18, 18, illetve a szitagliptin csoportjában $7 \%$-ban, hasmenés sorrendben 13 , 13 , valamint $7 \%$-ban volt észlelhető. $0,5 \mathrm{mg}$ szemaglutid mellett $2 \%$-ban, $1,0 \mathrm{mg}$ szemaglutid esetén $<1,0 \%$-ban, szitagliptin mellett $1 \%$-ban volt vércukor-önellenőrzéssel igazolt hypoglykaemia. Összesen 6 haláleset fordult elő, sorrendben 2, 1, illetve szitagliptin mellett 3 esetben, a vizsgálók szerint nem volt igazolható a halál egyértelmü kapcsolata az alkalmazott gyógyszerekkel. ${ }^{6}$

\section{SUSTAIN-3}

Az 56 hetes SUSTAIN-3 vizsgálatban 813 beteget randomizáltak 1:1 arányban heti egyszer 1,0 mg szemaglutid vagy heti egyszer $2,0 \mathrm{mg}$ exenatid-LAR készítmény kiegészítő injektálására, akik diabetese 1 vagy 2 orális antidiabeticum (változatlan dózisú metformin vagy metformin + szulfanilurea kombináció) ellenére nem volt jól beállítva.
A kiindulási átlagosan 8,3\%-os $\mathrm{HbA}_{1 c}$-érték szemaglutid mellett $1,5 \%$-kal, exenatid-LAR esetén 0,9\%-kal csökkent, a glykaemiás hatékonyság különbsége szignifikáns előnyt mutatott a szemaglutid vonatkozásában ( $\mathrm{p}<0,00001)$. A kiindulási, átlagosan 95,8 kg-os testsúly szemaglutid hatására 5,6 kgmal, exenatid-LAR esetén 1,9 kg-mal csökkent, a szemaglutid testsúly-előnye itt is szignifikánsnak bizonyult $(\mathrm{p}<0,0001)$. A szemaglutid-csoportban a betegek szignifikánsan nagyobb arányban érték el a $<7 \% \mathrm{HbA}_{1 \mathrm{c}}$-célértéket (67\% vs. $40 \%$ ) és a $\leq 6,5 \% \mathrm{HbA}_{1 \mathrm{c}}$-célértéket (47\% vs. $22 \%$ ) A p értéke mindkét esetben $<0,0001$. A fentiek értelmében az 1,0 mg szemaglutid szuperior a heti 2,0 mg exenatid-LAR-ral szemben mind a glykaemiás hatékonyság, mind a testsúlyra gyakorolt kedvező hatás tekintetében, egyúttal az injekciós helyen kialakuló lokális bőrreakció is lényegesen ritkább volt szemaglutid esetén (1\% vs. $22 \%)^{7}$

\section{SUSTAIN-4}

A 30 hetes SUSTAIN-4 tanulmányban az 1082 betegen változatlan dózisú metformin és szulfanilurea kiegészítésére adott heti 0,5, illetve 1,0 mg szemaglutid glykaemiás hatékonyságát vetették össze a napi $10 \mathrm{E}$ kiindulási adagról a reggeli éhomi 4,0-5,5 mmol/l-es plazmaglukóz elérése érdekében fokozatosan feltitrált glargin inzulinnal szemben. Döntően gastrointestinalis mellékhatások miatt a szemaglutid-csoportban $0,5 \mathrm{mg}$ adag mellett a betegek 14\%-a, az 1,0 mg adagú szemaglutid ágon $15 \%$-a hagyta abba a vizsgálatot, míg a glargin esetén a 7\%-os „lemorzsolódás” alapja az inzulin beadási helyén észlelt kipirulás, viszketés és urticaria volt. A kiindulási $8,2 \%$-os $\mathrm{HbA}_{1 \mathrm{c}}{ }^{-}$ értékről $0,5 \mathrm{mg}$ szemaglutid esetén átlagosan 1,21\%-kal (95\%-os CI: 1,10-1,31), heti 1,0 mg szemaglutid esetén átlagosan 1,64\%-kal (95\%-os CI: 1,10-1,31) lett kisebb, míg glargin inzulin mellett 0,83\%-os (95\%-os CI: $0,73-0,93)$ csökkenés volt elérhető, mindkét dózisú szemaglutid glykaemiás előnye szignifikáns volt $(\mathrm{p}<0,0001)$. A testsúly a kiindulási, átlagosan 93,45 kg-ról 0,5 mg szemaglutid mellett 3,47 kg-mal (95\%-os CI: 3,00-3,93), $1,0 \mathrm{mg}$ szemaglutid esetén átlagosan $5,17 \mathrm{~kg}$-mal csökkent (95\%-os CI: 4,17-5,66), ezzel szemben glargin inzulin alkalmazásakor a testsúly átlagosan 
1,15 kg-mal növekedett (95\%-os CI: 0,70-1,61). Itt is egyértelműen szignifikáns a szemaglutid mindkét adagjának előnye $(\mathrm{p}<0,0001)$. Súlyos vagy vércukor-önellenőrzéssel igazolt hypoglykaemia tekintetében is a szemaglutid volt egyértelműen előnyösebb (sorrendben: 4, 6, illetve glargin inzulin esetén $11 \%$ ). Összegezve: a szemaglutid mindkét adagban nagyobb mértékű $\mathrm{HbA}_{1 c}$-csökkentő és testsúlymérséklő hatással bír, mindezt egyértelműen kevesebb hypoglykaemiás epizód mellett, jól tolerálható az egyéb GLP-1-receptoragonistákhoz hasonlóan kedvező biztonságossági profil mellett. ${ }^{8}$

\section{SUSTAIN-5}

A 30 hetes SUSTAIN-5 vizsgálatban 397 bázisinzulin \pm metformin kezelés ellenére rosszul beállított, átlagosan 13,3 éves ismert diabetestartamú betegben vizsgálták a korábbi kezeléshez hozzáadott heti $0,5 \mathrm{mg}, 1,0 \mathrm{mg}$ szemaglutid, illetve placebo glykaemiás hatását. A kiindulási, átlagosan 8,4\%-os $\mathrm{HbA}_{1 \mathrm{c}}$-értékről 0,5 mg szemaglutid esetén átlagosan 1,4\%-os, heti 1,0 mg szemaglutid esetén átlagosan 1,8\%-os, a placebocsoportban $0,1 \%$-os csökkenés volt elérhető, mindkét dózisú szemaglutid glykaemiás előnye szignifikáns volt $(\mathrm{p}<0,0001)$. A testsúly a kiindulási, átlagosan 91,7 kg-ról 0,5 mg szemaglutid mellett $3,7 \mathrm{~kg}$-mal, $1,0 \mathrm{mg}$ szemaglutid esetén átlagosan $6,4 \mathrm{~kg}$-mal csökkent, míg placebo mellett csak $1,4 \mathrm{~kg}-\mathrm{mal}(\mathrm{p}<0,0001)$. A hypoglykaemiás epizódok gyakoriságában nem volt érdemi különbség. Az éhomi vércukor csökkenése nagyobb mértékü volt szemaglutid mellett, a kiindulási átlagosan $8,6 \mathrm{mmol} / \mathrm{l}$-ről sorrendben $1,6 \mathrm{mmol} / 1,2,4 \mathrm{mmol} / \mathrm{l}$, illetve placebo mellett 0,5 $\mathrm{mmol} / \mathrm{l}$ volt a javulás. A vizsgálat idő előtti abbahagyása gyakoribb volt a szemaglutid esetén (sorrendben: $4,5 \%, 6,1 \%$, illetve placebo esetén $0,8 \%$ ), döntően emésztőrendszeri mellékhatások, émelygés, hányinger, hányás, hasmenés miatt. ${ }^{9}$

\section{SUSTAIN-7}

A nyílt elrendezésű, randomizált, 40 hetes $3 b$ fázisú SUSTAIN-7 tanulmányban 1199 glykaemiásan nem jól kontrollált beteg a változatlan dózisú metformin kiegészítésére heti $1 \times 0,5 \mathrm{mg}$ szemaglutidot vs. heti $1 \times 0,75 \mathrm{mg}$ dulaglutidot, valamint heti $1 \times 1,0 \mathrm{mg}$ szemaglutidot vs. heti $1 \times 1,5 \mathrm{mg} \mathrm{du}-$ laglutidot kapott subcutan injekció formájában. A vizsgálatot a $\mathrm{HbA}_{1 \mathrm{c}}$ tekintetében non-inferioritásra és szuperioritásra, testsúly vonatkozásában szuperioritásra tervezték. A diabetes ismert átlagos időtartama 7,4 év, a kiindulási $\mathrm{HbA}_{1 \mathrm{c}}$ átlagosan $8,2 \%$ volt. Heti $0,5 \mathrm{mg}$ szemaglutid $1,5 \%$ $\mathrm{kal}$, heti $0,75 \mathrm{mg}$ dulaglutid $1,1 \%$-kal, heti $1,0 \mathrm{mg}$ szemaglutid 1,8\%-kal, míg heti $1,5 \mathrm{mg}$ dulaglutid 1,4\%-kal csökkentette a $\mathrm{HbA}_{1 \mathrm{c}}$-értéket, mindkét esetben a szemaglutid glykaemiás hatékonysága szignifikánsan nagyobb mértékű volt $(\mathrm{p}<0,0001)$. A testsúlycsökkentő hatás heti $0,5 \mathrm{mg}$ szemaglutid esetén 4,6 kg-os, heti $0,75 \mathrm{mg}$ dulaglutidnál $2,3 \mathrm{~kg}$ os, heti 1,0 mg szemaglutid alkalmazásakor $6,5 \mathrm{~kg}$ os, míg a heti $1,5 \mathrm{mg}$ dulaglutid esetén átlagosan 3,0 kg-os mértékü volt, e tekintetben is mindkét esetben a szemaglutid testsúlymérséklő hatékonysága szignifikánsan kifejezettebb volt $(\mathrm{p}<0,0001)$. A leggyakoribb mellékhatás emésztőszervi volt, a 0,5 mg szemaglutidot kapó betegek esetén 43\%ban, a heti 1,0 mg-os szemaglutid-kezelésben részesülő betegek esetén 44\%-ban, heti $0,75 \mathrm{mg}$ dulaglutid esetén 33\%-ban, míg 1,5 mg dulaglutid mellett 48\%-ban fordult elő. Ez volt a fenti gyógyszerek abbahagyásának leggyakoribb oka. Összegezve: mindkét dózistartományban a szemaglutid mind a glykaemiás kontroll, mind a testsúlycsökkentés tekintetében felülmúlta a dulaglutid hatását hasonló biztonságossági profil mellett. ${ }^{10}$ A 40 hetes vizsgálatban a legalább 5\%-os testsúlycsökkenést elérők aránya $0,5 \mathrm{mg}$ szemaglutid mellett $44 \%$, a minimum 10\%-os testsúlycsökkenést teljesítők aránya $14 \%$ volt, 1,0 mg szemaglutid esetén a fenti arányok sorrendben $63 \%$, illetve $27 \%$ volt, míg $0,75 \mathrm{mg}$ dulaglutid esetén a fenti adatok sorrendben az alábbiak voltak: $23 \%$, illetve $3 \%$, heti $1,5 \mathrm{mg}$ dulaglutid esetén $30 \%$, illetve $8 \%$. A SUSTAIN 1-5 és SUSTAIN-7 vizsgálatok legfontosabb adatait ${ }^{1,11,12}$ az 1. táblázatban tüntettük fel (egy tizedes értékre kerekített adatokkal).

\section{Szemaglutid hatása az idősebb populációban}

A 2-es típusú diabetes incidenciája növekszik az életkorral, férfiakban 65-69 éves korban, nők körében 75-79 éves életkorban a leggyakoribb. 
1. táblázat. A SUSTAIN 1-5 és a SUSTAIN-7 vizsgálatok fontosabb adatai és eredményei

\begin{tabular}{|c|c|c|c|c|c|c|}
\hline & SUSTAIN-1 & SUSTAIN-2 & SUSTAIN-3 & SUSTAIN-4 & SUSTAIN-5 & SUSTAIN-7 \\
\hline Alapkezelés & Gyógyszer-naiv & $\begin{array}{c}\text { MET } \\
\text { és/vagy TZD } \\
\text { kiegészítésére }\end{array}$ & $\begin{array}{c}\text { MET vagy } \\
\text { MET+SU } \\
\text { kiegészítésére }\end{array}$ & $\begin{array}{c}\text { MET vagy } \\
\text { MET+SU } \\
\text { kiegészítésére }\end{array}$ & $\begin{array}{l}\text { Bázisinzulin } \\
\pm \text { MET } \\
\text { kiegészítésére }\end{array}$ & $\begin{array}{c}\text { MET } \\
\text { kiegészítésére }\end{array}$ \\
\hline Vizsgált készítmény & $\begin{array}{c}\text { SEMA 0,5 mg/hét } \\
\text { SEMA 1,0 mg/hét } \\
\text { Placebo }\end{array}$ & $\begin{array}{l}\text { SEMA 0,5 mg/hét } \\
\text { SEMA 1,0 mg/hét } \\
\text { SITA } 100 \mathrm{mg} / \mathrm{nap}\end{array}$ & $\begin{array}{l}\text { SEMA } 1,0 \text { mg/hét } \\
\text { EXE-LAR 2,0 mg/hét }\end{array}$ & $\begin{array}{l}\text { SEMA 0,5 mg/hét } \\
\text { SEMA } 1,0 \mathrm{mg} / \mathrm{hét} \\
\text { Glargin inzulin }\end{array}$ & $\begin{array}{c}\text { SEMA 0,5 mg/hét } \\
\text { SEMA } 1,0 \mathrm{mg} / \mathrm{hét} \\
\text { Placebo }\end{array}$ & $\begin{array}{l}\text { SEMA } 0,5 \mathrm{mg} \text { vs. } \\
\text { DULA 0,75 mg } \\
\text { SEMA } 1,0 \mathrm{mg} \text { vs. } \\
\text { DULA } 1,5 \mathrm{mg}\end{array}$ \\
\hline $\begin{array}{l}\text { Kezelni tervezett (intent } \\
\text { to treat) betegek száma }\end{array}$ & 387 & 1225 & 813 & 1082 & 397 & 1199 \\
\hline Vizsgálat időtartama & 30 hét & 56 hét & 56 hét & 30 hét & 30 hét & 40 hét \\
\hline Primer végpont & $\mathrm{HbA}_{1 \mathrm{c}}$ & $\mathrm{HbA}_{1 \mathrm{c}}$ & $\mathrm{HbA}_{1 \mathrm{c}}$ & $\mathrm{HbA}_{1 \mathrm{c}}$ & $\mathrm{HbA}_{1 \mathrm{c}}$ & $\mathrm{HbA}_{1 \mathrm{c}}$ \\
\hline Kiindulási átlagéletkor & 53,7 év & 55,1 év & 56,6 év & 56,5 év & 58,8 év & 56 év \\
\hline Kiindulási átlag- $\mathrm{HbA}_{1 \mathrm{c}}$ & $8,1 \%$ & $8,1 \%$ & $8,3 \%$ & $8,2 \%$ & $8,4 \%$ & $8,2 \%$ \\
\hline Kiindulási átlagtestsúly & $91,6 \mathrm{~kg}$ & $89,5 \mathrm{~kg}$ & $95,8 \mathrm{~kg}$ & $93,4 \mathrm{~kg}$ & $91,7 \mathrm{~kg}$ & $95,2 \mathrm{~kg}$ \\
\hline Diabetes időtartama & 4,2 év & 6,6 év & 9,2 év & 8,6 év & 13,3 év & 7,4 év \\
\hline $\mathrm{HbA}_{1 \mathrm{c}}$ változása (\%) & $\begin{array}{l}\text { SEMA } 0,5:-1,5^{*} \\
\text { SEMA 1,0: }-1,6^{*} \\
\text { Placebo: }<-0,1\end{array}$ & $\begin{array}{l}\text { SEMA } 0,5:-1,3^{*} \\
\text { SEMA 1,0: }-1,6^{*} \\
\text { SITA 100: }-0,5\end{array}$ & $\begin{array}{l}\text { SEMA } 1,0:-1,5^{*} \\
\text { EXE-LAR } 2,0:-0,9\end{array}$ & $\begin{array}{l}\text { SEMA } 0,5:-1,2^{*} \\
\text { SEMA } 1,0:-1,6^{*} \\
\text { Glargin: }-0,8\end{array}$ & $\begin{array}{c}\text { SEMA 0,5: }-1,4^{*} \\
\text { SEMA 1,0: }-1,8^{*} \\
\text { Placebo: }-0,1\end{array}$ & $\begin{array}{l}\text { SEMA } 0,5:-1,5^{*} \\
\text { DULA } 0,75:-1,1 \\
\text { SEMA } 1,0:-1,8^{*} \\
\text { DULA } 1,5:-1,4\end{array}$ \\
\hline Testsúly változása (kg) & $\begin{array}{l}\text { SEMA 0,5: }-3,7^{*} \\
\text { SEMA 1,0: }-4,5^{*} \\
\text { Placebo: }-1,0\end{array}$ & $\begin{array}{l}\text { SEMA } 0,5:-4,3^{*} \\
\text { SEMA } 1,0:-6,1^{*} \\
\text { SITA } 100:-1,9\end{array}$ & $\begin{array}{l}\text { SEMA } 1,0:-5,6^{*} \\
\text { EXE-LAR } 2,0:-1,9\end{array}$ & $\begin{array}{l}\text { SEMA } 0,5:-3,5^{*} \\
\text { SEMA } 1,0:-5,2^{*} \\
\text { Glargin: }+1,2\end{array}$ & $\begin{array}{c}\text { SEMA 0,5: }-3,7^{*} \\
\text { SEMA 1,0: }-6,4^{*} \\
\text { Placebo: }-1,4\end{array}$ & $\begin{array}{l}\text { SEMA } 0,5:-4,6^{*} \\
\text { DULA 0,75: }-2,3 \\
\text { SEMA 1,0:-6,5* } \\
\text { DULA } 1,5:-3,0\end{array}$ \\
\hline
\end{tabular}

SEMA: szemaglutid, SITA: szitagliptin, MET: metformin, SU: szulfanilurea, TZD: thiazolidindion, EXE-LAR: exanatid-LAR, DULA: dulaglutid * $p<0,0001$ vs. komparátor gyógyszer mellett észlelt változás

Időskorban különös súllyal esik latba a hypoglykaemiás epizódok kerülése, a biztonságos antihyperglykaemiás kezelés. A SUSTAIN 1-5 post hoc analízisét elvégezve, a 65 év alatti és fölötti betegek adatait vizsgálva azt találták, hogy a heti 0,5 $\mathrm{mg}$ vagy $1,0 \mathrm{mg}$ szemaglutid biztonságosan alkalmazható a 65-75 éves korosztályban is, azonban a 75 évnél idősebb populációt illetően nincs elegendő adat (a SUSTAIN 1-5 tanulmányban mindöszsze 156 beteg volt 75 éves vagy annál idősebb, azaz a teljes vizsgált betegpopuláció mindössze 3\%-a tartozott az ilyen idős betegcsoportba). A fentiek miatt 75 éves kor fölött óvatosság szükséges a szemaglutid alkalmazásával. Ezzel szemben a 65 év fölötti T2DM-esek populációját jól reprezentálta a SUSTAIN 1-5 vizsgálatban szereplő több mint $850 \geq 65$ évnél idősebb beteg. Jelen ismereteink szerint a gyakran többszörös társbetegséggel rendelkező 65-75 éves T2DM-es betegek körében a szemaglutid a vizsgált komparátor gyógyszerekkel összevetve egyértelműen kedvező hatású a $\mathrm{HbA}_{1 c^{-}}$ értékre és a testsúlyra. ${ }^{13}$

\section{További kiegészítő klinikai adatok}

Egy észtországi költség-hatékonysági vizsgálatban a napi egyszeri $1,2 \mathrm{mg}$ liraglutidot és a heti 1,0 mg szemaglutidot összehasonlítva az életminőséget tekintve, valamint a heti egyszeri alkalmazású szemaglutid az adherencia és perzisztencia vonatkozásában egyértelműen költség-hatékonynak bizonyult. ${ }^{14}$ Sharma és mtsai 8, legalább 20 hetes RCT alapján elvégzett network-metaanalízisben azt találták, hogy a szemaglutid mindkét terápiás adag (heti 0,5, illetve 1,0 mg) mellett kifejezettebben csökkenti a $\mathrm{HbA}_{1 \mathrm{c}}$-értéket, mint az SGLT-2gátlók. A heti 1,0 mg szemaglutid a testsúlyra és az éhomi plazmaglukózszintre egyértelműen kedvezőbb hatású, összehasonlítva az SGLT-2-gátlókkal, míg a systolés vérnyomást illetően nem találtak különbséget. ${ }^{15}$ A jelenleg zajló $3 b$ fázisú SUSTAIN-8 vizsgálat a szemaglutidot hasonlítja össze az SGLT2-gátló canagliflozinnal.

Heti $0,5 \mathrm{mg}$ szemaglutid mellett a systolés vérnyomás átlagosan 3,5-5,1 Hgmm-rel, heti 1,0 mg 
szemaglutid esetén 5,4-7,3 Hgmm-rel csökkent orális antidiabeticumokkal vagy bázisinzulinnal együtt alkalmazva, ugyanakkor a diastolés vérnyomás nem csökkent érdemben a komparátor vegyületekkel végzett összehasonlítás során. Súlyos hypoglykaemiát elsősorban szemaglutidnak szulfanilureával (a betegek 1,2\%-a, azaz 0,03 esemény/betegév) vagy bázisinzulinnal történő kombinációja esetén észleltek (a betegek 1,5\%-a, azaz 0,02 esemény/betegév). ${ }^{16,17}$

Egy randomizált, egyközpontú, placebo-kontrollált, keresztezett $(2 \times 12$ hetes kezelési periódust alkalmazó ún. „crossover”) vizsgálatban 30 betegen azt találták, hogy a szemaglutid-kezelés szignifikánsan csökkenti az éhomi plazmaglukóz és glukagonszintet, mind az éhomi, mind a postprandialis lipid-anyagcserére kedvező hatású, valamint a standard, szénhidrátban gazdag reggeli tesztétkezést követő 1 . órás, korai fázisú gyomorürülést 27\%-kal $(\mathrm{p}=0,0012)$ lassítja (paracetamolfelszívódási tesztet alkalmazva), a későbbi fázist viszont nem befolyásolja. Szemaglutid hatására az éhomi triglicerid- és VLDL-szint szignifikánsan csökken, az éhomi FFA- és apoB48-szint nem változik. Zsírban gazdag tesztétkezést követően szignifikánsan csökkenti a postprandialis triglicerid- (40,7\%kal), a VLDL- (42,8\%-kal) és az ApoB48-szintet $(49,6 \%$-kal) (a p értéke minden esetben $<0,01) .{ }^{18}$

\section{Összefoglalás}

A fentiekben részletezett adatok alapján nem meglepő, hogy a heti 0,5 , illetve $1,0 \mathrm{mg}$ szemaglutid kiváló (az eddig vizsgált komparátor antihyperglykaemiás gyógyszereket meghaladó) glykaemiás hatékonyságú és testsúlycsökkentő hatású. Minimális hypoglykaemia-rizikó és a fokozatos dózistitrálás mellett vállalható, átmeneti, többnyire enyhe emésztőrendszeri mellékhatásokkal rendelkezik. A SUSTAIN-6 kardiovaszkuláris kimeneteli vizsgálatban kifejezett előnyt igazoló korszerű, hosszú hatású GLP-1-receptoragonista. A heti egyszeri adagolás a gyógyszeralkalmazás adherenciájára és perzisztenciájára, valamint az életminőségre igen előnyös. Jelen tudásunk szerint az ismert diabeteses retinopathia mellett fokozott óvatosság, rendszeres szemészeti kontroll, valamint megfontoltabb dózistitrálás ajánlott. ${ }^{19,20}$
Az alkalmazási előirat szerint a kezdő adag szemaglutid 4 hétig heti egyszer $0,25 \mathrm{mg}$, majd a dózis heti egyszer 0,5 mg-ra növelendő. Ezt követően (legkorábban újabb 4 hét múlva) a jobb glykaemiás kontroll érdekében heti egyszer 1,0 mg-ra növelhető a szemaglutid adagja. ${ }^{21}$ 


\section{lrodalom}

1. Goldenberg RM, Steen 0: Semaglutide: Review and place in therapy for adults with type 2 diabetes. Can J Diabetes 2018 Jun 5. pii: S1499-2671 (18)30 109-6. [Epub ahead of print] doi:10.1016/j.jcjd.2018.05.008

2. Marso SP, Bain SC, Consoli A, Eliaschewitz FG, Jódar E, Leiter LA, et al.; SUSTAIN-6 investigators. Semaglutide and cardiovascular outcomes in patients with type 2 diabetes. N Engl J Med 2016; 375: 1834-1844. doi:10.1056/NEJMoa1607141

3. Davies MJ, D'Alessio DA, Fradkin J, Kernan WN, Mathieu C, Mingrone G, et al:: Management of hyperglycemia in type 2 diabetes, 2018. A consensus report by the American Diabetes Association (ADA) and the European Association for the Study of Diabetes (EASD). Diabetes Care 2018; 41: 2669-2701. doi:10.1007/s00125-018-4729-5

4. Sharma D, Verma S, Vaidya S, Kalia K, Tiwari V: Recent updates on GLP-1 agonists: current advancements \& challenges. Biomed Pharmacother 2018; 108: 952-962. doi:10.1016/j.biopha.2018.08.088

5. Sorli C, Harashima SI, Tsoukas GM, Unger J, Karsbøl JD, Hansen T, et al.: Efficacy and safety of once-weekly semaglutide monotherapy vs. placebo in patients with type 2 diabetes (SUSTAIN 1): a doubleblind, randomised, placebo-controlled, parallel-group, multinational, multicentre phase 3a trial. Lancet Diabetes Endocrinol 2017; 5: 251-260. doi:10.1016/52213-8587(17)30013-X

6. Ahrén B, Masmiquel L, Kumar H, Sargin M, Karsbøl JD, Jacobsen SH, et al: Efficacy and safety of once-weekly semaglutide vs. once-daily sitagliptin as an add-on to metformin, thiazolidinediones, or both, in patients with type 2 diabetes (SUSTAIN 2): a 56-week, double-blind, phase 3a, randomised trial. Lancet Diabetes Endocrinol 2017; 5: 341-354. doi:10.1016/52213-8587(17)30092-X

7. Ahmann AJ, Capehorn M, Charpentier G, Dotta F, Henkel E, Lingvay I, et al: Efficacy and safety of once-weekly semaglutide vs. exenatide ER in subjects with type 2 diabetes (SUSTAIN 3): A 56-week, open-label, randomized clinical trial. Diabetes Care 2018; 41: 258-266. doi:10.2337/dc17-0417

8. Aroda VR, Bain SC, Cariou B, Piletič M, Rose L, Axelsen M, et al.: Efficacy and safety of once-weekly semaglutide vs. once-daily insulin glargine as addon to metformin (with or without sulfonylureas) in insulin-naive patients with type 2 diabetes (SUSTAIN 4): a randomised, open-label, parallel-group, multicentre, multinational, phase 3a trial. Lancet Diabetes Endocrinol 2017; 5: 355-366. doi:10.1016/52213-8587(17)30085-2

9. Rodbard HW, Lingvay I, Reed J, de la Rosa R, Rose L, Sugimoto D, et al: Semaglutide added to basal insulin in type 2 diabetes (SUSTAIN 5): A randomized, controlled trial. J Clin Endocrinol Metab 2018; 103: 2291-2301. doi:10.1210/jc.2018-00070

10. Pratley RE, Aroda VR, Lingvay I, Lüdemann J, Andreassen C, Navarria A, SUSTAIN 7 investigators: Semaglutide vs. dulaglutide once weekly in patients with type 2 diabetes (SUSTAIN 7): a randomised, openlabel, phase 3b trial. Lancet Diabetes Endocrinol 2018; 6: 275-286. doi:10.1016/52213-8587(18)30024-X

11. Aroda V, Ahmann A, Cariou B, Chow F, Davies MJ, Jódar E, et al.: Comparative efficacy, safety, and cardiovascular outcomes with once-weekly subcutaneous semaglutide in the treatment of type 2 diabetes: Insights from the SUSTAIN 1-7 trials. Diabetes Metab 2019 Jan 4. pii: S1262-3636 (18) 30222-2. [Epub ahead of print] doi:10.1016/j.diabet.2018.12.001

12. Handelsman Y, Wyne K, Cannon A, Shannon M, Schneider D: Glycemic efficacy, weight effects, and safety of once-weekly glucagon-like peptide-1 receptor agonists. J Manag Care Spec Pharm 2018; 24(9-a Suppl): S14-S29. doi:10.18553/jmcp.2018.24.9-a.s14

13. Warren $M$, Chaykin L, Trachtenbarg D, Nayak G, Wijayasinghe N, Cariou $B$ : Semaglutide as a therapeutic option for elderly patients with type 2 diabetes: Pooled analysis of the SUSTAIN 1-5 trials. Diabetes Obes Metab 2018; 20:2291-2297. doi:10.1111/dom.13331
14. Malkin SJP, Russel-Szymczyk M, Liidemann G, Volke V, Hunt B: Once-weekly semaglutide vs. once-daily liraglutide for the treatment of type 2 diabetes: A long-term cost-effectiveness analysis in Estonia. Diabetes Ther 2019; 10: 159-176. doi:10.1007/s13300-018-0542-x

15. Sharma R, Wilkinson L, Vrazic H, Popoff E, Lopes S, Kanters S, et al: Comparative efficacy of once-weekly semaglutide and SGLT-2 inhibitors in type 2 diabetic patients inadequately controlled with metformin monotherapy: a systematic literature review and network meta-analysis. Curr Med Res Opin 2018; 34: 1595-1603. doi:10.1080/03007995.2018.1476332

16. DeVries JH, Desouza C, Bellary S, Unger J, Hansen OKH, Zacho J, et al.: Achieving glycaemic control without weight gain, hypoglycaemia, or gastrointestinal adverse events in type 2 diabetes in the SUSTAIN clinical trial programme. Diabetes Obes Metab 2018; 20: 2426-2434. doi:10.1111/dom.13396

17. Ahrén B, Atkin SL, Charpentier G, Warren ML, Wilding JPH, Birch S, et al: Semaglutide induces weight loss in subjects with type 2 diabetes regardless of baseline BMI or gastrointestinal adverse events in the SUSTAIN 1 to 5 trials. Diabetes Obes Metab 2018; 20:2210-2219. doi:10.1111/dom.13353

18. Hjerpsted JB, Flint A, Brooks A, Axelsen MB, Kvist T, Blundell J: Semaglutide improves postprandial glucose and lipid metabolism, and delays first-hour gastric emptying in subjects with obesity. Diabetes Obes Metab 2018; 20 : 610-619. doi:10.1111/dom. 13120

19. Vilsbøll T, Bain SC, Leiter LA, Lingvay I, Matthews D, Simó R, et al.: Semaglutide, reduction in glycated haemoglobin and the risk of diabetic retinopathy. Diabetes Obes Metab 2018; 20: 889-897. doi: $10.1111 /$ dom. 13172

20. Coon SA, Crannage EF, Kerwin LC, Guyton JE: Semaglutide once-weekly: improved efficacy with a new safety warning. Expert Rev Clin Pharmacol 2018; 11: 1061-1072. doi:10.1080/17512433.2018.1534201

21. Ozempic alkalmazási elöirás. https://www.ema.europa.eu/en/medicines/ human/EPAR/ozempic

Közlésre érkezett: 2019. február 20.

Közlésre elfogadva: 2019. március 6.

A szerzö levelezési címe:

Dr. Balogh Zoltán

Debreceni Egyetem Klinikai Központ, Általános

Orvostudományi Kar, Belgyógyászati Intézet,

Debrecen

4032 Debrecen, Nagyerdei krt. 98. Pf. 19.

E-mail: baloghz@belklinika.com 